\title{
Forecasting of Fibre Yield of Jute at Harvesting Stage using Regression based Statistical Model for Nadia District of West Bengal
}

\author{
Sirjan Murmu and S. A. Khan* \\ Department of Agricultural Meteorology and physics, Bidhan Chandra Krishi \\ Viswavidyalaya, Mohanpur, Nadia 741252, West Bengal, India \\ *Corresponding author
}

\section{A B S T R A C T}

\begin{tabular}{|l|}
\hline Ke y w o r d s \\
Jute, Weather, \\
$\begin{array}{l}\text { Forecasting, } \\
\text { Regression }\end{array}$ \\
\hline Article Info \\
\hline $\begin{array}{l}\text { Accepted: } \\
\text { 20 June } 2021 \\
\text { Available Online: } \\
\text { 10 July 2021 }\end{array}$ \\
\hline
\end{tabular}

Forecasting of fibre yield of jute (Corchorus spp.) is required for storage, marketing, import, export strategy. Weather is the main factor which affects crop growth and yield. Variability in weather causes the losses in the yield. Forecasting fibre yield of jute can be done with the help of weather parameters. Therefore model based on weather parameters can be provide reliable forecast for jute yield. In this study, the focus was on the development of crop yield forecasting model through stepwise linear regression technique using weather variables and historic yield data from 1995 to 2017 of Nadia district, West Bengal. The model use 24 original parameters, 24 generated weather variables, 18 interaction weather variables, 18 generated interaction weather variables and Time trend (T) during growing period and yield data of jute. Model development was carried out from 1995 to 2013. From the models it can be inferred that among the different variables, total rainfall, afternoon vapour pressure, afternoon soil temperature at $30 \mathrm{~cm}$ depth and interactive value between temperature range with rainfall, rainy days and morning relative humidity were the most influencing predictors for fibre yield of jute for the districts. The models were validated with the actual yield for the period 2014 to 2017. Accuracy of these models tested with coefficient of determination $\left(\mathrm{R}^{2}\right)$.

\section{Introduction}

Jute is considered as the golden fibre of India. It is used as packing materials, textile and non-textile sectors in large and small industries. It is also used as leafy vegetables. Results revealed that jute leaf is rich source of antioxidant such as beta carotene, vitamin $\mathrm{C}$ and disease fighting phenols. Jute is eco- friendly, biodegradable and has much higher $\mathrm{CO}^{2}$ assimilation rate which provides an opportunity for survival and growth of jute industry in the era of environmental concern.

Global production of jute and allied fibres is around 3.0 million tonnes, $92.5 \%$ of which comes from India and Bangladesh alone. India ranks first in area and production of jute 
followed by Bangladesh. India earns about Rs. 1400 crores /annum through export of jute goods.

Climate determines the type of crop grown in a region and the weather determines the yield. Many investigations were earlier undertaken to determine the impact of weather parameters on crop yield and to develop weather based models to estimate the crop yield before its harvest.

Apart from weather, the crop yield is also dependent on technology that includes the application of fertilizer, improved management practices, plant protection, high yielding varieties, irrigation, etc.

The productivity has increased owing to application of improved technology of crop production through passage of time and hence year is used as one of the independent variables for fitting regression equation for yield estimation.

Several investigators have utilized correlation and regression methods to examine the impact of weather variables on crop yield.

Estimation of yield before harvest is of immense help in planning strategy of food imports and distribution, internal procurements, storage and export.

Influences of weather parameters on crop yield were worked out in wheat by Appa Rao (1983), in rice by Jain et al., (1980) and Khan et al., (1995), in groundnut by Khatri and Patel (1983), in jute by Khan and Saha (1994). Agrawal et al., (1986) studied the joint effects of weather parameters using generated weather variables.

Correlation coefficient between yield and weather variables and correlation coefficient between yield and product of two variables were used to multiply the original weather parameters to get generated weather variables. Mehta et al., (2010) predicted potato yield in Uttar Pradesh by using generated weather variables.

The present study was conducted with following objectives: 1 . To assess the impact of weather parameters on fibre yield of jute. 2 .

To develop weather based multiple regression models for forecasting of fibre yield of jute. 3 . To validate the weather based multiple regression models with the data not included in the development of the models.

\section{Materials and Methods}

The investigation aims at to assess the influence of weather factors prevailing during the growing season on fibre yield and develop regression models for prediction of jute grown in Nadia district of West Bengal.

The growing season of jute for fibre production considered in this study were of 119 days $\left(14^{\text {th }}\right.$ to $\left.30^{\text {th }} \mathrm{SMW}\right)$.

\section{Crop yield data}

The average fibre yield of jute for the period from 1995 to 2017 in respect of Nadia district was collected from the Directorate of Agriculture, Govt. of West Bengal.

\section{Weather data}

In order to evaluate the impact of weather parameters on yield and to develop weatherbased regression models for pre-harvest forecast of yield of jute, daily meteorological data for the period from 1995 to 2017 were collected from the Agrometeorological Observatory, All India Coordinated Research Project on Agrometeorology (AICRP), B.C.K.V., Kalyani. 
For this purpose, district-level yield was regressed with 24 original parameters [maximum temperature (Tmax), minimum temperature (Tmin), mean temperature (Tmean), temperature range (TR), bright sunshine hours (BSH), morning relative humidity (RH I), afternoon relative humidity (RH II), morning soil temperature at $5 \mathrm{~cm}$ depth (ST I $5 \mathrm{~cm}$ ), morning soil temperature at $15 \mathrm{~cm}$ depth (ST I $15 \mathrm{~cm}$ ), morning soil temperature at $30 \mathrm{~cm}$ depth (ST I $30 \mathrm{~cm})$, afternoon soil temperature at $5 \mathrm{~cm}$ depth (ST II $5 \mathrm{~cm}$ ), afternoon soil temperature at $15 \mathrm{~cm}$ depth (ST II $15 \mathrm{~cm}$ ), afternoon soil temperature at $30 \mathrm{~cm}$ depth (ST II $30 \mathrm{~cm}$ ), morning vapour pressure (AVP I), afternoon vapour pressure (AVP II), morning vapour pressure deficit (VPD I), afternoon vapour pressure deficit (VPD II)], total evaporation (TEVP), total rainfall (TRF), dry spell (DS), wet spell (WS) and rainy days (RD)), 24 generated weather variables, 18 interaction weather variables (product of 2 weather parameters), 18 generated interaction weather variables and time trend $(\mathrm{T})$ to get best regression model.

For each variable, indices were worked out as follows: $\mathrm{Z} 10=$ simple accumulation of a variable, Z11=weighted accumulation of a weather variable; Z120=simple accumulation of interaction (product of two variables); Z121=weighted accumulation of interaction.

11: first one (1) is value of a variable and second one (1) is correlation coefficient

12: product of variables 1 and $2(1 * 2)$

120: of variable 1 and $2(1 * 2)$

121: of weighted values $\left[\mathrm{r}^{*}(1 * 2)\right]$

Due to adoption of HYVs, and improved package of practices, crop yield has increased, the time trend $(\mathrm{T})$ expressed in years was considered as one of the variables in this study.

The association between yield and time/year (T) is significant, detrended yield (difference between actual and predicted yields based on following regression equation involving actual yield and years).

In the present study, trend effect was significant. The trend equation is $\mathrm{Y}=2318.561 * *+22.615 * * \mathrm{~T} \quad(\mathrm{R} 2=0.496 * *)$, where $\mathrm{Y}=$ Fibre yield in $\mathrm{kg} / \mathrm{ha}, \mathrm{T}=$ Year number (1995 to 2017) has been included for correcting long term upward and downward trend in yields (Agrawal et al., 1983); database $=23$ years.

Detrended yields estimated as stated above were employed for stepwise regression analysis for developing multiple regression model (Agrawal et al., 1983).

Original weather variables were correlated with detrended yield and correlation coefficients so obtained were used to multiply original weather data to get generated weather variables which were summed up from 1 st week to harvest of the season.

The correlation values so obtained were used to multiply the original product of two variables to obtain generated interaction variables which were accumulated from 1st week to harvest.

Due to technological advancement, the time trend (T) was considered as one of the independent variables in the regression analysis.

All original weather parameters, generated single and interaction variables and time trend employed for stepwise regression analysis (SPSS 16.0 version) for developing multiple regression models for forecasting yield at the 
time of harvest. All the stepwise regression models fitted for prediction of yield were tested for their suitability as appropriate models for forecasting of fibre yields at the time of harvest based on lower prediction error values. The yields of years which were not included in the development of models were predicted through the regression models and compared with the actual yields of corresponding years. In the validation analysis, the data of four years from 2014 to 2017 were used.

\section{Results and Discussion}

The values of weekly weather parameters during jute growing season have been presented in Table1., which revealed that maximum, minimum and temperature range over different weeks were 34.8, 25.5 and 9.2 ${ }^{\circ} \mathrm{C}$ respectively and their corresponding $\mathrm{C}$.V. values were $4.5,3.4$ and $23.4 \%$, respectively.

The lowest rainfall ( $\mathrm{RF}$ in $\mathrm{mm}$ ) recorded was $7.4 \mathrm{~mm}$ in $14^{\text {th }} \mathrm{SMW}$ and highest rainfall recorded was 84.6 in $29^{\text {th }} \mathrm{SMW}$.

Result revels that the lowest evaporation (EVP in $\mathrm{mm}$ ) recorded was $16.6 \mathrm{~mm}$ in $30^{\text {th }} \mathrm{SMW}$ and highest evaporation recorded was 33.5 in $17^{\text {th }}$ SMW. Average relative humidity ( $\mathrm{RH}$ in $\%$ ), dry spell (days) and wet spell (days) were 92.5, 3.8 and 3.1 respectively with C.V. value $2.5,43.4$ and 52 respectively. Mean rainy days

Fig.1 Weekly total rainfall (mm)

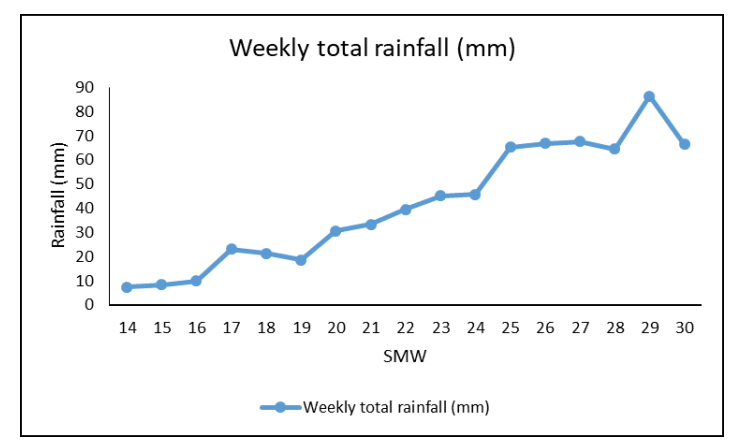

(days), VPII $(\mathrm{kPa})$ and STII $\left({ }^{\circ} \mathrm{C}\right)$ at $30 \mathrm{~cm}$ depth were 2.1, 3.3 and 32.1 respectively with C.V. value 54, 9.4 and $3.3 \%$ respectively.

The regression equations along with adj. $R^{2}$ and std. error were represented in Table 2. Predicted and actual yield were developed for Nadia districts of West Bengal state through step-wise regression method presented in Table 3.

The performance of those regression models were validated with actual fibre yield of jute for the years 2014-17.

The accuracy of these crop yield forecast models ware measured using $\mathrm{R}^{2}$. From the models it can be inferred that among the different variables, the total rainfall, afternoon vapour pressure, afternoon soil temperature at $30 \mathrm{~cm}$ depth and interactive value between temperature range with rainfall, rainy days and morning relative humidity were the most influencing predictors for fibre yield of jute for Nadia districts with \% of deviation between -23.3 to 5.8 .

The developed models have reasonably good $\mathrm{R}^{2}$ i.e. 55 to $97 \%$. Highest $\mathrm{R}^{2}$ value was found in Model 8 while lowest in Model 1.

Therefore the model 8 can be used to some extent for forecasting the fibre yield of jute for Nadia districts of West Bengal.

Fig.2 Weekly total evaporation (mm)

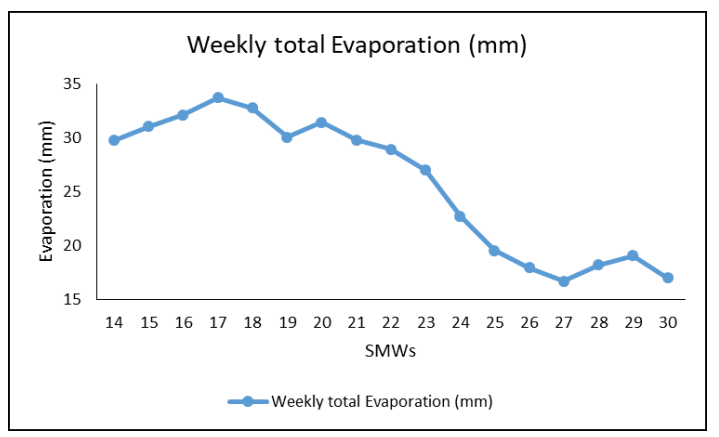


Table.1 Agroclimatic environment during different weeks under the growing season of jute

\begin{tabular}{|c|c|c|c|c|c|c|c|c|c|c|c|}
\hline \multirow[t]{2}{*}{ SMW } & \multicolumn{11}{|c|}{ Weather variables } \\
\hline & $\begin{array}{c}\mathbf{R F} \\
(\mathbf{m m})\end{array}$ & $\begin{array}{l}\text { EVP } \\
(\mathbf{m m})\end{array}$ & $\begin{array}{c}\text { Tmax } \\
\left({ }^{\circ} \mathbf{C}\right)\end{array}$ & $\begin{array}{c}\text { Tmin } \\
\left({ }^{\circ} \mathbf{C}\right)\end{array}$ & $\begin{array}{c}\text { TR } \\
\left({ }^{\circ} \mathbf{C}\right)\end{array}$ & $\begin{array}{l}\text { RHI } \\
(\%)\end{array}$ & $\begin{array}{l}\text { Dry } \\
\text { spell }\end{array}$ & $\begin{array}{l}\text { Wet } \\
\text { spell }\end{array}$ & $\begin{array}{c}\text { Rainy } \\
\text { days }\end{array}$ & $\begin{array}{r}\text { VPII } \\
(\mathrm{kPa})\end{array}$ & $\begin{array}{c}\text { STII } 30 \\
\left({ }^{\circ} \mathbf{C}\right)\end{array}$ \\
\hline 14 & 7.4 & 29.5 & 35.4 & 23.6 & 11.9 & 92.1 & 5.8 & 1.2 & 0.8 & 2.7 & 31.3 \\
\hline 15 & 9.6 & 30.8 & 36.2 & 24.0 & 12.2 & 89.9 & 6.0 & 1.0 & 0.7 & 2.8 & 32.2 \\
\hline 16 & 9.9 & 32.2 & 36.7 & 25.1 & 11.6 & 90.1 & 6.1 & 0.9 & 0.5 & 3.0 & 33.1 \\
\hline 17 & 22.1 & 33.5 & 36.5 & 24.6 & 11.8 & 90.4 & 5.3 & 1.7 & 1.0 & 3.0 & 33.0 \\
\hline 18 & 21.7 & 32.5 & 35.9 & 24.8 & 11.1 & 89.4 & 4.8 & 2.3 & 1.5 & 3.1 & 33.0 \\
\hline 19 & 18.1 & 30.1 & 35.8 & 25.4 & 10.4 & 90.9 & 5.2 & 1.8 & 1.1 & 3.2 & 33.1 \\
\hline 20 & 29.9 & 31.1 & 36.2 & 25.3 & 10.9 & 91.3 & 4.4 & 2.6 & 1.8 & 3.3 & 33.3 \\
\hline 21 & 32.7 & 29.6 & 36.0 & 26.0 & 10.1 & 90.9 & 4.3 & 2.7 & 1.8 & 3.4 & 33.2 \\
\hline 22 & 39.8 & 28.9 & 36.1 & 26.3 & 9.8 & 91.6 & 4.2 & 2.8 & 2.0 & 3.5 & 33.1 \\
\hline 23 & 43.7 & 27.0 & 35.8 & 26.4 & 9.3 & 91.8 & 4.3 & 2.8 & 1.8 & 3.5 & 32.9 \\
\hline 24 & 44.4 & 23.0 & 34.7 & 26.4 & 8.3 & 93.1 & 3.6 & 3.4 & 2.2 & 3.6 & 32.2 \\
\hline 25 & 62.5 & 19.8 & 33.7 & 26.2 & 7.5 & 94.4 & 2.6 & 4.4 & 3.2 & 3.6 & 31.5 \\
\hline 26 & 65.5 & 17.8 & 33.0 & 26.2 & 6.8 & 95.4 & 1.8 & 5.3 & 3.0 & 3.6 & 31.0 \\
\hline 27 & 67.7 & 16.8 & 32.7 & 26.0 & 6.7 & 95.8 & 1.8 & 5.3 & 3.5 & 3.6 & 30.6 \\
\hline 28 & 64.3 & 18.3 & 33.1 & 26.4 & 6.7 & 95.4 & 2.0 & 5.0 & 3.5 & 3.6 & 31.0 \\
\hline 29 & 84.7 & 19.0 & 32.4 & 26.1 & 6.3 & 96.1 & 1.3 & 5.7 & 3.8 & 3.6 & 30.7 \\
\hline 30 & 72.3 & 16.7 & 32.5 & 26.1 & 6.4 & 95.1 & 1.7 & 5.3 & 3.8 & 3.6 & 30.6 \\
\hline MEAN & 41.0 & 25.7 & 34.9 & 25.6 & 9.3 & 92.6 & 3.8 & 3.2 & 2.1 & 3.3 & 32.1 \\
\hline S.D. \pm & 24.7 & 6.3 & 1.6 & 0.9 & 2.2 & 2.3 & 1.7 & 1.7 & 1.1 & 0.3 & 1.1 \\
\hline C.V.(\%) & 60.3 & 24.4 & 4.5 & 3.4 & 23.5 & 2.5 & 43.4 & 52.0 & 54.0 & 9.4 & 3.3 \\
\hline
\end{tabular}

Table.2 Regression equations involving weather parameters for forecasting of fibre yield of jute (kg/ha) Database: 1995 to 2013

\begin{tabular}{|c|c|c|c|}
\hline $\begin{array}{l}\text { Model } \\
\text { No. }\end{array}$ & Regression equation & Adj. $\mathbf{R}^{2}$ & $\begin{array}{l}\text { Std. } \\
\text { error }\end{array}$ \\
\hline 1. & $\mathrm{Y}=55.607 *+2.207 * * \mathrm{X}_{1}$ & $0.550 * *$ & 106.9 \\
\hline 2. & $\mathrm{Y}=-758.533 * *+1.73 * * \mathrm{X}_{1}+0.0364 * * \mathrm{X}_{2}$ & $0.714 * *$ & 85.3 \\
\hline 3. & $\mathrm{Y}=-28.352+1.549 * * \mathrm{X}_{1}+0.334 * * \mathrm{X}_{2}+170.288 * * \mathrm{X}_{3}$ & $0.793 * *$ & 72.5 \\
\hline 4. & $\begin{array}{c}\mathrm{Y}=-1901.565 * *+1.304 * * \mathrm{X}_{1}+0.312 * * \mathrm{X}_{2}+382.949 * * \mathrm{X}_{3}+ \\
48.985 * * \mathrm{X}_{4}\end{array}$ & $0.868 * *$ & 57.8 \\
\hline 5. & $\begin{array}{c}\mathrm{Y}=-2370.013 * *-0.306 \mathrm{X}_{1}+0.299 * * \mathrm{X}_{2}+443.927 * * \mathrm{X}_{3}+ \\
61.524 * * \mathrm{X}_{4}+0.224 * \mathrm{X}_{5}\end{array}$ & $0.905 * *$ & 49.2 \\
\hline 6. & $\begin{array}{c}\mathrm{Y}=-2266.528 * *+0.298 * * \mathrm{X}_{2}+429.903 * * \mathrm{X}_{3}+58.847 * * \mathrm{X}_{4}+ \\
0.187 * * \mathrm{X}_{5}\end{array}$ & $0.910 * *$ & 47.8 \\
\hline 7. & $\begin{array}{c}\mathrm{Y}=-2075.072 * *+0.331 * * \mathrm{X}_{2}+488.941 * * \mathrm{X}_{3}+66.048 * * \mathrm{X}_{4}+ \\
0.238 * * \mathrm{X}_{5}-14.785 * * \mathrm{X}_{6}\end{array}$ & $0.953 * *$ & 34.7 \\
\hline 8. & $\begin{array}{c}\mathrm{Y}=-2386.846 * *+0.312 * * \mathrm{X}_{2}+525.018 * * \mathrm{X}_{3}+75.138 * * \mathrm{X}_{4}+ \\
0.186 * * \mathrm{X}_{5}-16.438 * * \mathrm{X}_{6}+2.054 * \mathrm{X}_{7}\end{array}$ & $0.968 * *$ & 28.4 \\
\hline
\end{tabular}

$*=$ Significant at $5 \%$ level, $* *=$ Significant at $1 \%$ level, $\mathrm{X}_{1}=$ Gen. TRF, $\mathrm{X}_{2}=$ Gen. TR.RHI, $\mathrm{X}_{3}=$ Gen. VPII, $\mathrm{X}_{4}=$ VPII, $\mathrm{X}_{5}=$ Gen. TR.RF, $\mathrm{X}_{6}=$ Gen. STII $30, \mathrm{X}_{7}=$ Gen. TR.RD. 
Table.3 Comparison between observed and predicted fibre yields of jute for the years not included for development of regression models.

\begin{tabular}{|c|c|c|c|c|c|c|c|c|c|}
\hline $\begin{array}{c}\text { Model } \\
\text { No. }\end{array}$ & Year & $\begin{array}{c}\text { Actual } \\
\text { yield } \\
\text { (kg/ha) }\end{array}$ & $\begin{array}{c}\text { Predicted } \\
\text { yield } \\
\text { (kg/ha) }\end{array}$ & $\begin{array}{c}\% \\
\text { Deviation }\end{array}$ & $\begin{array}{l}\text { Model } \\
\text { No. }\end{array}$ & Year & $\begin{array}{c}\text { Actual } \\
\text { yield } \\
\text { (kg/ha) }\end{array}$ & $\begin{array}{c}\text { Predicted } \\
\text { yield } \\
\text { (kg/ha) }\end{array}$ & $\begin{array}{c}\% \\
\text { Deviation }\end{array}$ \\
\hline \multirow[t]{4}{*}{1.} & 2014 & 2797.2 & 2867.6 & -2.5 & \multirow[t]{4}{*}{5.} & 2014 & 2797.2 & 3116.6 & -11.4 \\
\hline & 2015 & 2552.4 & 2493.2 & 2.3 & & 2015 & 2552.4 & 2403.9 & 5.8 \\
\hline & 2016 & 2898 & 2904.4 & -0.2 & & 2016 & 2898 & 2904 & -0.2 \\
\hline & 2017 & 2819 & 2730.7 & 3.1 & & 2017 & 2819 & 3362.9 & -19.2 \\
\hline \multirow[t]{4}{*}{2.} & 2014 & 2797.2 & 2958.6 & -5.7 & \multirow[t]{4}{*}{6.} & 2014 & 2797.2 & 3111.5 & -11.2 \\
\hline & 2015 & 2552.4 & 2477.7 & 2.9 & & 2015 & 2552.4 & 2410.2 & 5.5 \\
\hline & 2016 & 2898 & 2898.6 & -0.02 & & 2016 & 2898 & 2899 & -0.03 \\
\hline & 2017 & 2819 & 2663.4 & 5.5 & & 2017 & 2819 & 3335.3 & -18.3 \\
\hline \multirow[t]{4}{*}{3.} & 2014 & 2797.2 & 2949 & -5.4 & \multirow[t]{4}{*}{7.} & 2014 & 2797.2 & 3124.7 & -11.7 \\
\hline & 2015 & 2552.4 & 2364.1 & 7.3 & & 2015 & 2552.4 & 2472.9 & 3.1 \\
\hline & 2016 & 2898 & 2822.1 & 2.6 & & 2016 & 2898 & 2845 & 1.8 \\
\hline & 2017 & 2819 & 2872.9 & -1.9 & & 2017 & 2819 & 3399 & -20.5 \\
\hline \multirow[t]{4}{*}{4.} & 2014 & 2797.2 & 3098.1 & -10.7 & \multirow[t]{4}{*}{8.} & 2014 & 2797.2 & 3151 & -12.6 \\
\hline & 2015 & 2552.4 & 2449 & 4.04 & & 2015 & 2552.4 & 2485.4 & 2.6 \\
\hline & 2016 & 2898 & 2875.2 & 0.7 & & 2016 & 2898 & 2869.7 & 0.9 \\
\hline & 2017 & 2819 & 3238.3 & -14.8 & & 2017 & 2819 & 3476.07 & -23.3 \\
\hline
\end{tabular}


Fig.3 Weekly avg. TR $\left({ }^{\circ} \mathrm{C}\right)$

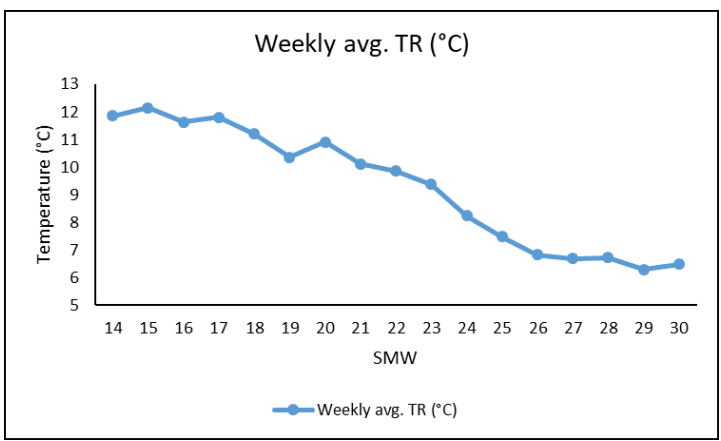

Fig.5 Weekly avg. VPII (kPa).

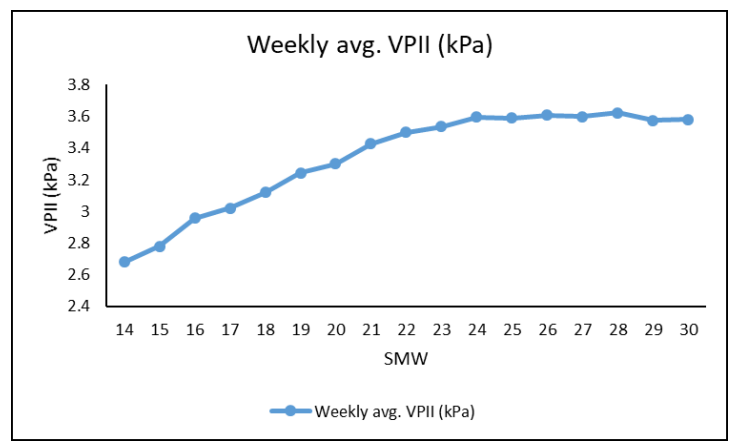

Fig.7 Weekly avg. STII $30\left({ }^{\circ} \mathrm{C}\right)$.

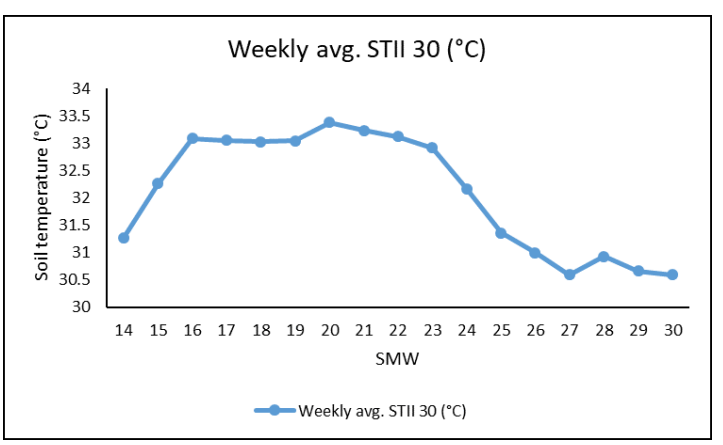

Fig.4 Weekly total RD (days)

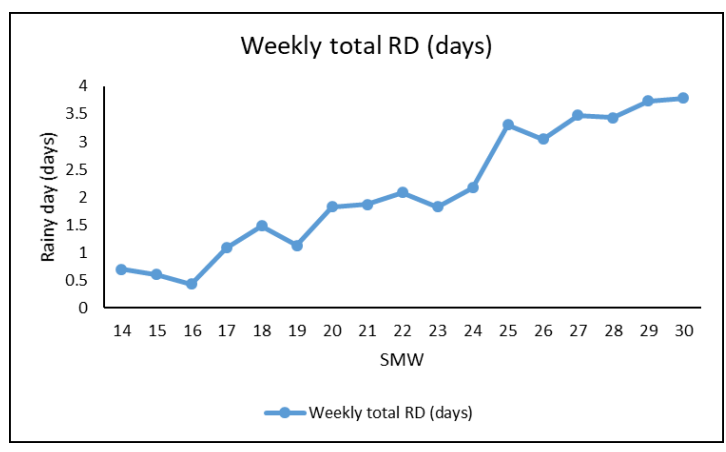

Fig.6 Weekly avg. RHI (\%).

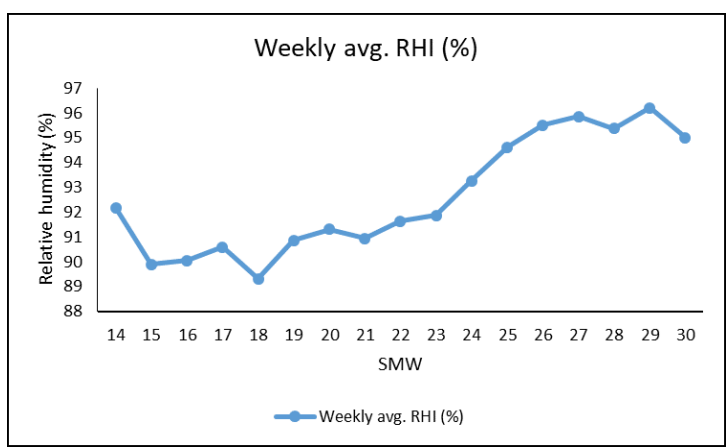

Fig.8 Variation in weeklyrainfall and evaporation $(\mathrm{mm})$.

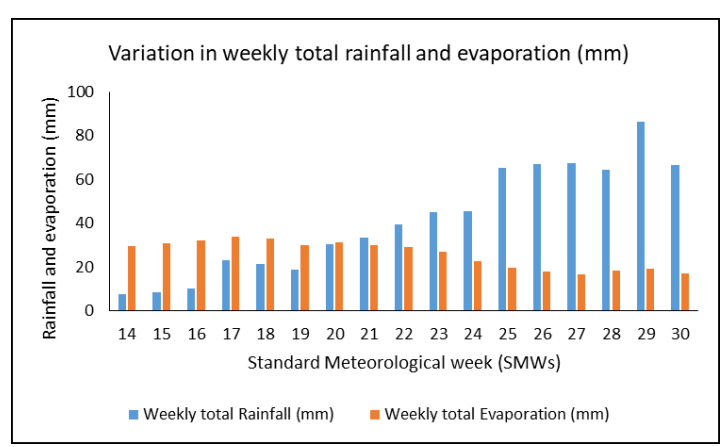


Fig.9 Seasonal total rainfall (mm).

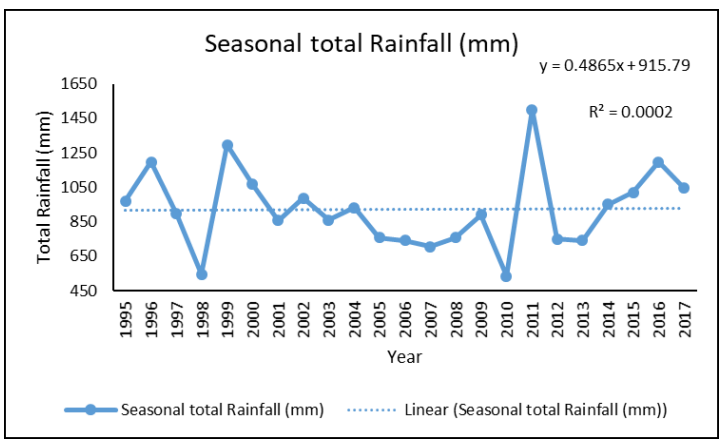

Fig.11 Seasonal avg. TR $\left({ }^{\circ} \mathrm{C}\right)$.

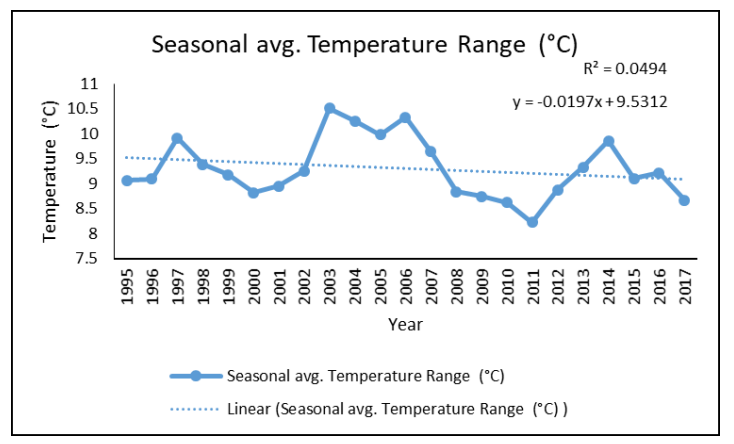

Fig.13 Seasonal avg. VPII (kPa).

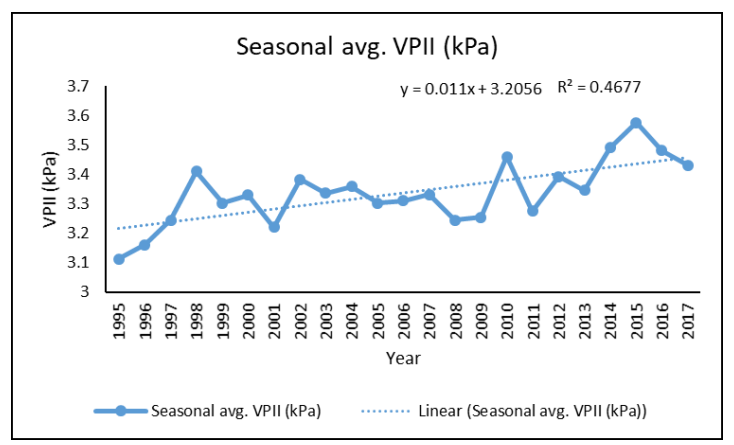

Fig.10 Seasonal total evaporation (mm).

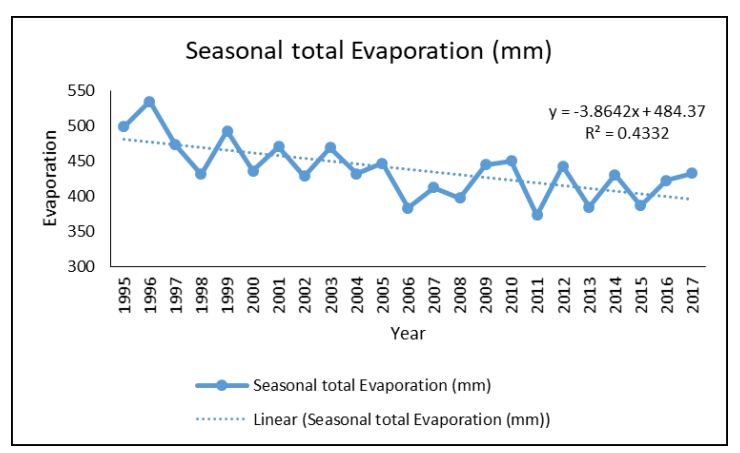

Fig.12 Seasonal total RD (days).

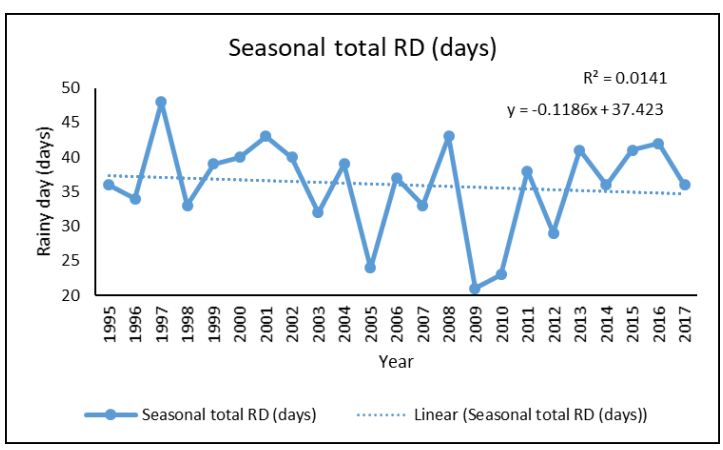

Fig.14 Seasonal avg. RHI (\%).

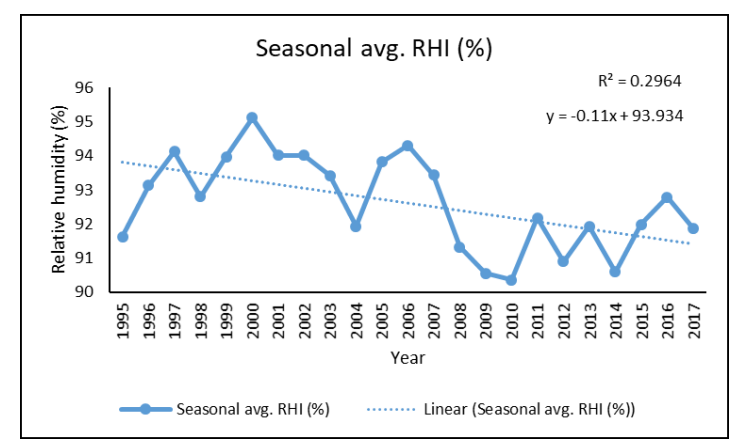


Fig.15 Seasonal avg. STII $30\left({ }^{\circ} \mathrm{C}\right)$.

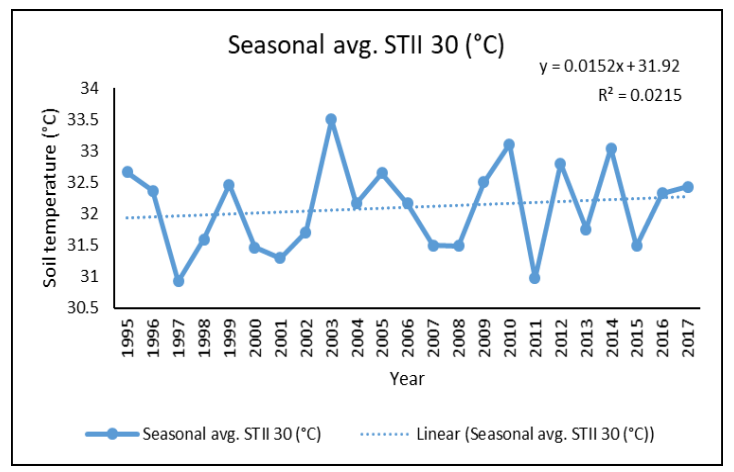

\section{Acknowledgement}

The authors express obligation to the Directorate of Agriculture, Govt. of West Bengal for providing jute fibre yield data and Agrometeorological Observatory, All India Coordinated Research Project on Agrometeorology (AICRP), B.C.K.V., Kalyani for providing meteorological data. The authors also express their thanks to Department of Agro-meteorology, B.C.K.V. for providing platform for this study as well as reviewers for their constructive comment.

\section{References}

Agrawal, R., Jain, R. C., Jha, M. P. 1983. Joint effects of weather variables on rice yield. Mausam. 34 (2): 189-194.

Agrawal, R., Jain, R. C., Jha, M. P. 1986. Models for studying rice-crop weather relationship. Mausam. 37 (1): 67-70.

Appa Rao, G. 1983. Estimation of wheat yields over Punjab using district and state model. Mausam. 34(3):275-280.
Fig.16 Variation in seasonal rainfall and evaporation (mm).

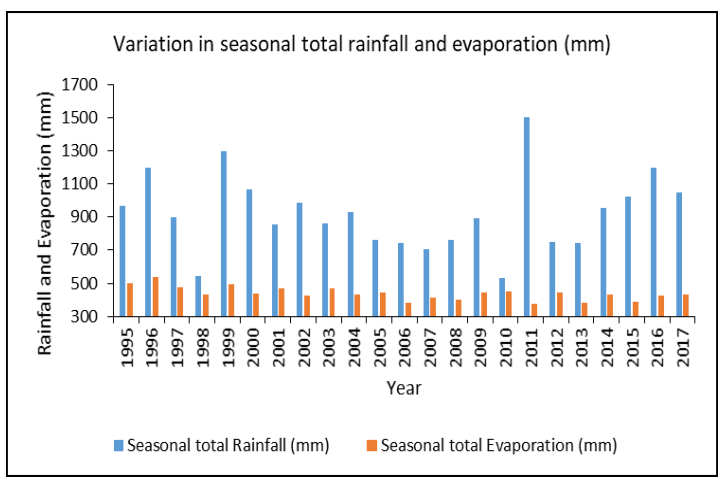

Jain, R. C., Agrawal, R. and Jha, M. P. 1980. Effect of climatic variables on rice yield and its forecast. Mausam, 31(3): 591-96.

Khan, S. A., Saha, G. 1994. Influence of rainfall and technology on fiber yields of tossa jute (Corchorus olitorius). Environment and Ecology. 12(1): 143146.

Khan, S. A., Majumdar, A., Mandai, B. K., Pramanik, M. and Chaudhuri, S. 1995. Agrometeorological study for forecasting the yields of winter rice and mustard in West Bengal. Environment and Ecology. 13(3):7 16720.

Khatri, T. J. and Patel, R. M. 1983. Use of yield prediction model for scheduling irrigation to groundnut. Indian J. agric. Sci. 53: 831-832.

Mehta, S. C., Pal, S. and Vinod, K. 2010. Weather based models for forecasting potato yield in Uttar Pradesh. IASRI Publication.

\section{How to cite this article:}

Sirjan Murmu and Khan, S. A. 2021. Forecasting of Fibre Yield of Jute at Harvesting Stage using Regression based Statistical Model for Nadia District of West Bengal. Int.J.Curr.Microbiol.App.Sci. 10(07): 730-738. doi: https://doi.org/10.20546/ijcmas.2021.1007.079 